\title{
PATTERN OF REPORTED SEXUAL ASSAULT CASES IN ASWAN GOVERNORATE, A RETROSPECTIVE STUDY (2010 -2015)
}

\author{
Nora Z. Abdellah ${ }^{\mathbf{1}}$ and Hamdy Fathy Ali $^{2}$ \\ Forensic medicine and clinical Toxicology department, Faculty of medicine, Assiut \\ University, Egypt ${ }^{1}$ \\ Forensic medicine and Toxicology department, Faculty of medicine, Aswan University, \\ Egypt $^{2}$
}

\begin{abstract}
Background: Sexual assault is a worldwide crime that occurs in most countries. Most sexual assaults are not reported and hidden, thus there are no accurate statistics on how many offenses occur. Purpose: A retrospective descriptive statistical study to investigate the pattern of sexual assaults in Aswan from archives of Forensic Medicine Authority for years (2010 to 2015). Results: Male victims represented more than half $(54.3 \%)$ of the reported cases and mostly were adolescents and unmarried. The mean of victims' age was 15.15, while the mean of age of assailants was 22 years old. There was a strong positive correlation between age of victims and age of the assailants. $89.1 \%$ of the cases were either anal or vaginal penetration or both $(52.1 \%, 28.3 \%$, and $8.7 \%$ respectively). $84.62 \%$ of anal penetrative assaults victims were males. Seminal fluid of the assailant was detected in only $6(13 \%)$ of the reported cases. 4 victims died after the assault; one male victim showed fractures of skull bones and brain lacerations. Three female victims was poisoned by hair dyes. Conclusion. It is necessary to emphasize that males also could be victims of sexual assault and male children are at significant risk of sexual abuse.
\end{abstract}

Keywords: sexual assaults, sexual violence, rape

Corresponding author: Nora Z. Abdellah; Forensic and Clinical Toxicology Department, Faculty of Medicine, Assiut University. Email: nora.z.a@ hotmail.com

\section{INTRODUCTION}

Sexual assault is defined as: "any sexual act, attempt to obtain a sexual act, unwanted sexual comments or advances, or acts to traffic, or otherwise directed, against a person's sexuality using coercion, by any person regardless of their relationship to the victim" (WHO, 2002). Sexual assault may range from rape to physically less intrusive sexual contacts (Akinlusi et al., 2014).

Sexual assault is a problem that affects all socioeconomic classes and affects millions worldwide (DeVore and Sachs, 2011). Sexual assault affects the lives of millions of women worldwide, regardless of geographical location, age, race, marital status or sexual orientation (Du Mont and White, 2007). While most reports on sexual assaults did not include male victims, sexual assaults were also encountered among men. Masho and Anderson (2009) suggested that male victims of sexual assault were likely to suffer more, to be depressed and to have suicidal ideas.

Genital and general body injuries are the immediate complications of sexual assault that can be fatal in some cases (Amenu and Hiko, 2014). Sexual assault victims are also at risk for acquiring sexually transmitted 
infections as Neisseria gonorrhoeae, Chlamydia trachomatis, human papillomavirus, and human immunodeficiency virus (HIV) infections (Seña et al., 2015).

Considering the above observations, this study aims to investigate the pattern of sexual assaults in Aswan from archives of Forensic Medicine Authority for years (2010 to 2015).

\section{MATERIAL \& METHODS}

A retrospective descriptive study of reported sexual assault victims to Aswan Forensic Medicine Authority (records from $1^{\text {st }}$ of January 2010 to $31^{\text {st }}$ of December 2015). Records of sexual assaults (46 cases) were analyzed as regard type of assault and interval between the assault and reporting to authorities. Data regarding age and gender of both victims and assailants, the presence of general physical injuries, local injuries and detection of semen were collected. Data were analyzed using one-way Annova, independent $\mathrm{T}$ test, Pearson test, descriptive analysis of data was calculated in terms of frequency and percentage.

Ethical considerations: Confidentiality of all records in this study were protected and all ethical aspects related to research on records in Assiut University were implicated in the study after the approval of the ethical committee.

\section{RESULTS}

The total number of recorded cases in the period of the study (2010 to 2015) was 46 cases. Table (1) demonstrates that the highest percentage of sexual assaults were encountered in 2012 records representing $28.26 \% \quad$ (13 cases) followed by 2014 with $17.40 \%$ (8 cases), then 2010 with percentage of $15.22 \%$ (7 cases), and lastly the years of 2011, 2013 and 2015 with 6 cases recorded in each year (13.04\%). The number of assaults were unrelated to the population (P-Value: 830 ).

Male victims represented $54.3 \%$ (25 cases) of reported cases, while females represented $45.7 \%$ (21 cases). $91.3 \%$ of victims were unmarried while married victims represented $8.7 \%$ of cases only (one male and three females) Table (2) and Fig (1\&2). Regarding the age of victims; the youngest reported case was 3 years old male child and the oldest victim was 38 years male. The mean age of victims was $15.15 \pm 8.22$ years. $32(69.56 \%)$ of reported cases were under 18 years old. Victims aged between 11 and 20 years ( $2^{\text {nd }}$ decade of life) represented the highest percentage of assault victims (47.83\%). Victims aged 10 years or less (the first decade of life represented the second highest group of victims (32.61\%), while there were no victims in the age group 41-50 years. Tables ( $3 \& 4)$ and Figs ( $3 \& 4)$.

Independent T-test showed no significant difference between the mean of age of male and female victims ( $\mathrm{p}$ value 0.099). The mean of age of female victims was 17.33 , while the mean of male victim's age was 13.32. Table (5) and fig. (5). One of the male victims was a prisoner.

As regard the age of assailant, table (4) shows that most of assailants were from 11 to 30 years (43 cases). Highest percentage of assailants aged between 11 and 20 years $(47.83 \%)$, while assailant in their $3^{\text {rd }}$ decade of life (2130 years) represented the second highest group of assailants (45.65\%). The mean of assailant's age was $22 \pm$ 6.821 with the minimum age was 15 years and the maximum age was 45 
years. Table (6) and fig. (6).

There was a strong positive correlation (significance of Pearson correlation $=0.689^{* *}$ ) between ages of victims and ages of assailants. In our study; 9 offenders were juveniles (less than 18 years), all victims of juvenile offenders were children (from 3 to 11 years), 8 out of 9 victims were male children representing $88.88 \%$ of their victims. Only one juvenile offender assaulted a female child. 37 of offenders were adults (above 18 years). 23 victims of adults' offenders were less than 18 years (from 3 to 17 years), representing $62.16 \%$ of their victims. Adult victims were the target of adult offenders in 14 cases representing $37.84 \%$. Fig. (7).

There was no significant difference (p-value 0.194) between mean of ages of assailants that assaulted females $(23.57 \pm 6.11)$ and those who assaulted males (21.24 \pm 5.85$)$. Fig. (8).

$41(89.1 \%)$ of the reported cases were either anal or vaginal penetration or both. $24(52.1 \%)$ of cases were anal intercourse, 13 (28.3\%) were vaginal, 4 $(8.7 \%)$ were both vaginal and anal, while $5(10.9 \%)$ were anal fondling. $91.66 \%$ of forced anal penetration cases were males. Table (7) shows that 13 out of 21 female victims were assaulted by vaginal penetration, while 2 females were assaulted by anal penetration and 4 female victims were assaulted by both anal and vaginal penetration. Assaults by anal fondling were encountered in 2 female victims. 22 out of 25 male victims were assaulted by anal penetration, while only 3 male victims were assaulted by anal fondling. Table (8). The distribution of forced anal penetration among victims according to gender is shown in table (9) and Fig. (9).

Table (10) and fig. (10) show the duration between the assault and reporting the incident. Sixteen cases (34.8\%) were reported 2 days after the assault, 10 cases $(21.7 \%)$ were reported 3 days after the assault. The shortest period between the assault and the reporting was one day and longest duration was one year. Pearson test demonstrated a weak positive correlation between age of victim and the duration of time between the sexual assault and reporting it (Significance 0.158). Fig. (11)

Table (11) demonstrates the presence of a previous history of sexual assaults, positive findings on general and local exanimation, and detection of seminal fluid on victims' bodies. Ten of the reported cases $(21.7 \%)$ had a positive history of previous sexual assaults. Six male victims $(11,16,21$, 22, 24 and 38 years old) reported a previous history of forced anal penetration, 3 female victims (all the 3 were 16 years old) reported previous vaginal intercourse, and an eighteen years old female reported previous vaginal and anal assaults.

Twenty-eight $(60.9 \%)$ of cases showed positive signs of local violence on local examination. five cases (4 males and one female) showed recent anal tears. The male victims aged 10 , 12,12 and 16 years while the female victim was 21 years old. A five years old child showed recent contusions and abrasions around the anus. Eight cases showed signs of habitual anal intercourse (6 males and 2 females). 8 females showed recent tear of hymen and 6 females showed old tears of hymen. Seminal fluid of the assailant was detected in only $6(13 \%)$ of the reported cases.

12 cases $(26.1 \%)$ showed positive signs of general violence or struggle; these signs ranged from contusions on 
face and lips to contusions and abrasions all over the body. 4 victims died after the assault; one male victim (18 years old) showed fracture of skull bones and brain lacerations. Three female victims (18, 20 and 28 years) were poisoned by hair dyes. Table (12).

Table (1): Distribution of sexual assaults through years of the study duration and its relation to population (2010-2015)

\begin{tabular}{|c|c|c|}
\hline Year & Frequency (percentage) & Population of Aswan Governorate* \\
\hline $\mathbf{2 0 1 0}$ & $7(15.22 \%)$ & 1278978 \\
\hline $\mathbf{2 0 1 1}$ & $6(13.04 \%)$ & 1308589 \\
\hline $\mathbf{2 0 1 2}$ & $13(28.26 \%)$ & 1340279 \\
\hline $\mathbf{2 0 1 3}$ & $6(13.04 \%)$ & 1374985 \\
\hline $\mathbf{2 0 1 4}$ & $8(17.40 \%)$ & 1412300 \\
\hline $\mathbf{2 0 1 5}$ & $6(13.04 \%)$ & 1431488 \\
\hline Total & $46(100 \%)$ & P-Value: .830 \\
\hline \multicolumn{2}{|c}{} \\
\hline
\end{tabular}

Table (2): Distribution of victims according to gender and marital status

\begin{tabular}{|c|c|c|c|}
\hline & Males & Females & Total \\
\hline & $25(54.3 \%)$ & $21(45.7 \%)$ & $46(100 \%)$ \\
\hline Married & 1 & 3 & $4(8.7 \%)$ \\
\hline Unmarried & 24 & 18 & $42(91.3 \%)$ \\
\hline
\end{tabular}

\section{Gender of Assailant}

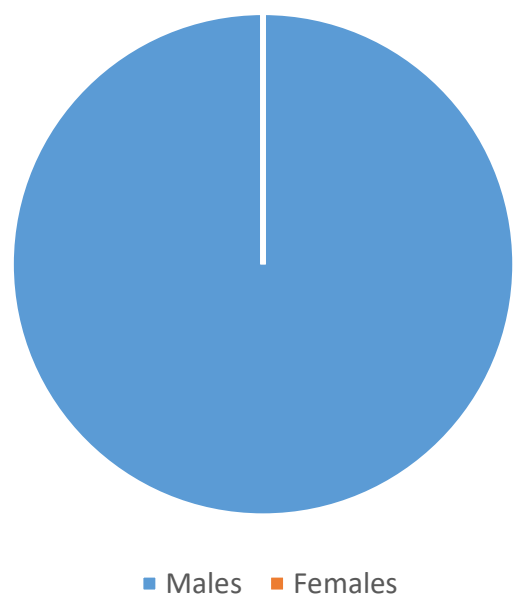

Figure (1): A pie chart showing distribution of assailants of sexual assaults according to gender 


\section{Marital status}

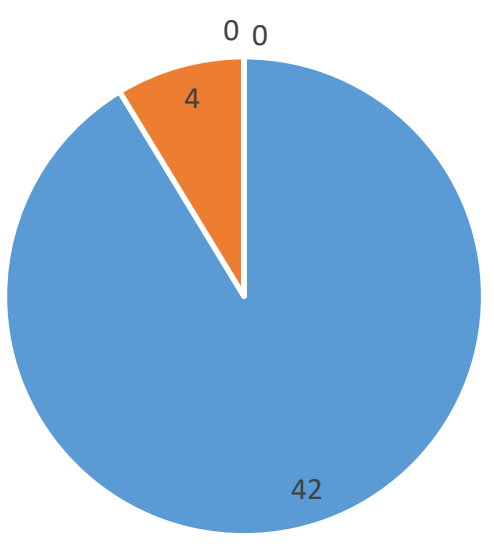

- Unmarried - Married

Figure (2): A pie chart showing the distribution of victims according to marital status.

Table (3): Descriptive analysis of age of the Victim

\begin{tabular}{|l|l|}
\hline & Age of the Victim \\
\hline Mean & 15.152 \\
\hline Median & 15.50 \\
\hline SD & 8.219 \\
\hline Minimum & 3 \\
\hline Maximum & 38 \\
\hline
\end{tabular}

Table (4): Distribution of age of the victims and assailants

\begin{tabular}{|c|c|c|}
\hline Age decade & $\begin{array}{c}\text { Victims } \\
\text { Frequency (percentage) }\end{array}$ & $\begin{array}{c}\text { Assailant } \\
\text { Frequency (percentage) }\end{array}$ \\
\hline Birth - >10 years & $15(32.61 \%)$ & 0 \\
\hline $11->20$ years & $22(47.83 \%)$ & $22(47.83 \%)$ \\
\hline $21->30$ years & $6(13.04 \%)$ & $21(45.65 \%)$ \\
\hline $31->40$ years & $3(6.52 \%)$ & $2(4.35 \%)$ \\
\hline $41->50$ years & 0 & $1(2.17 \%)$ \\
\hline Total & 46 & 46 \\
\hline
\end{tabular}




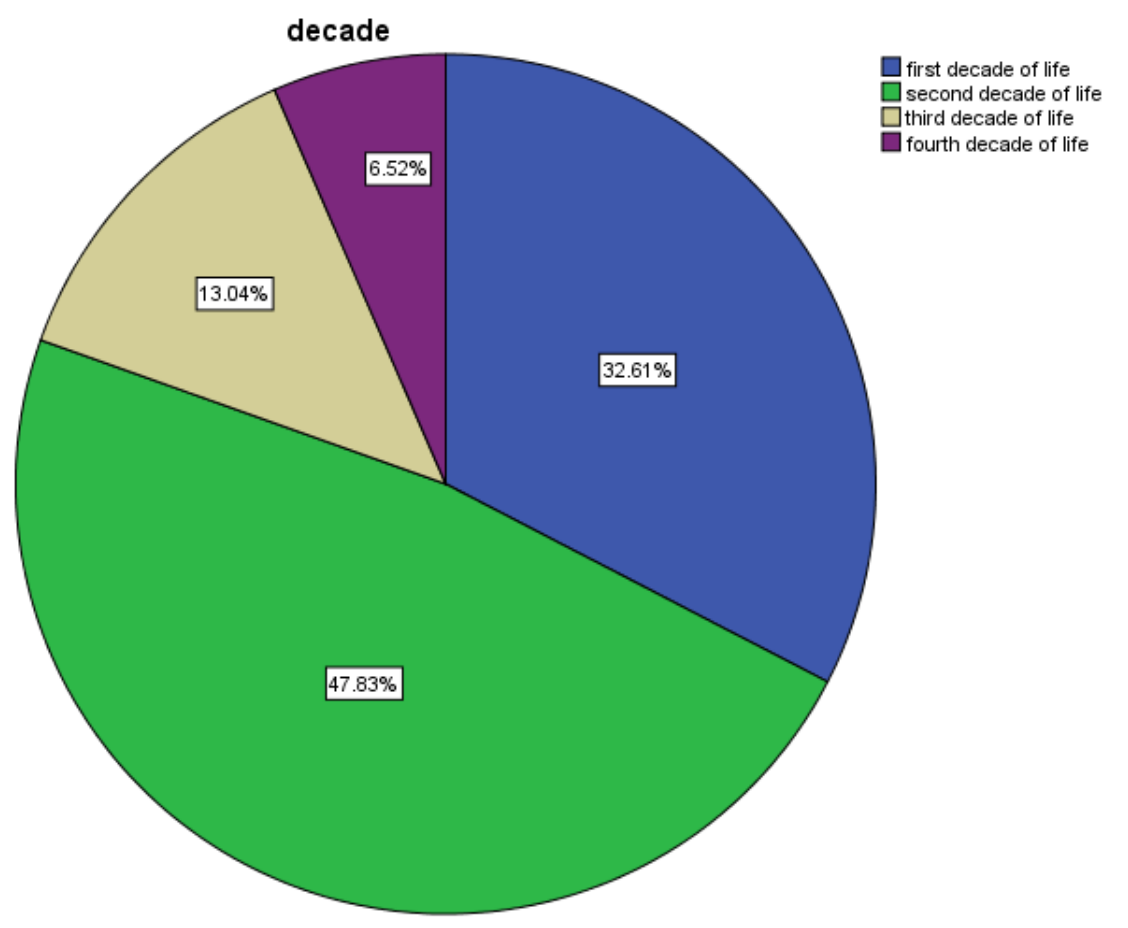

Figure (3): A pie chart showing distribution of sexual assaults victims' age

Table (5): Distribution of victim's age according to gender

\begin{tabular}{|l|l|l|}
\hline Gender of victim & Number of victims & Mean of age in years \pm SD \\
\hline Male & 25 & $13.32 \pm 8.96$ \\
\hline Female & 21 & $17.33 \pm 6.81$ \\
\hline Total & 46 & \\
\hline
\end{tabular}

Age of victims

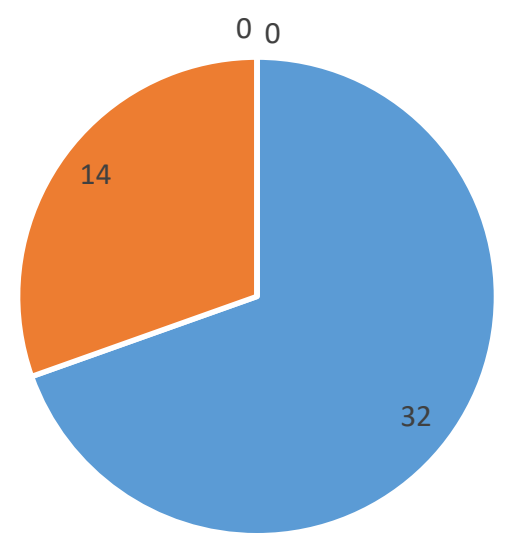

- Less than 18 years $\quad$ More than 18 years

Figure (4): A pie chart showing frequency of minor victims 


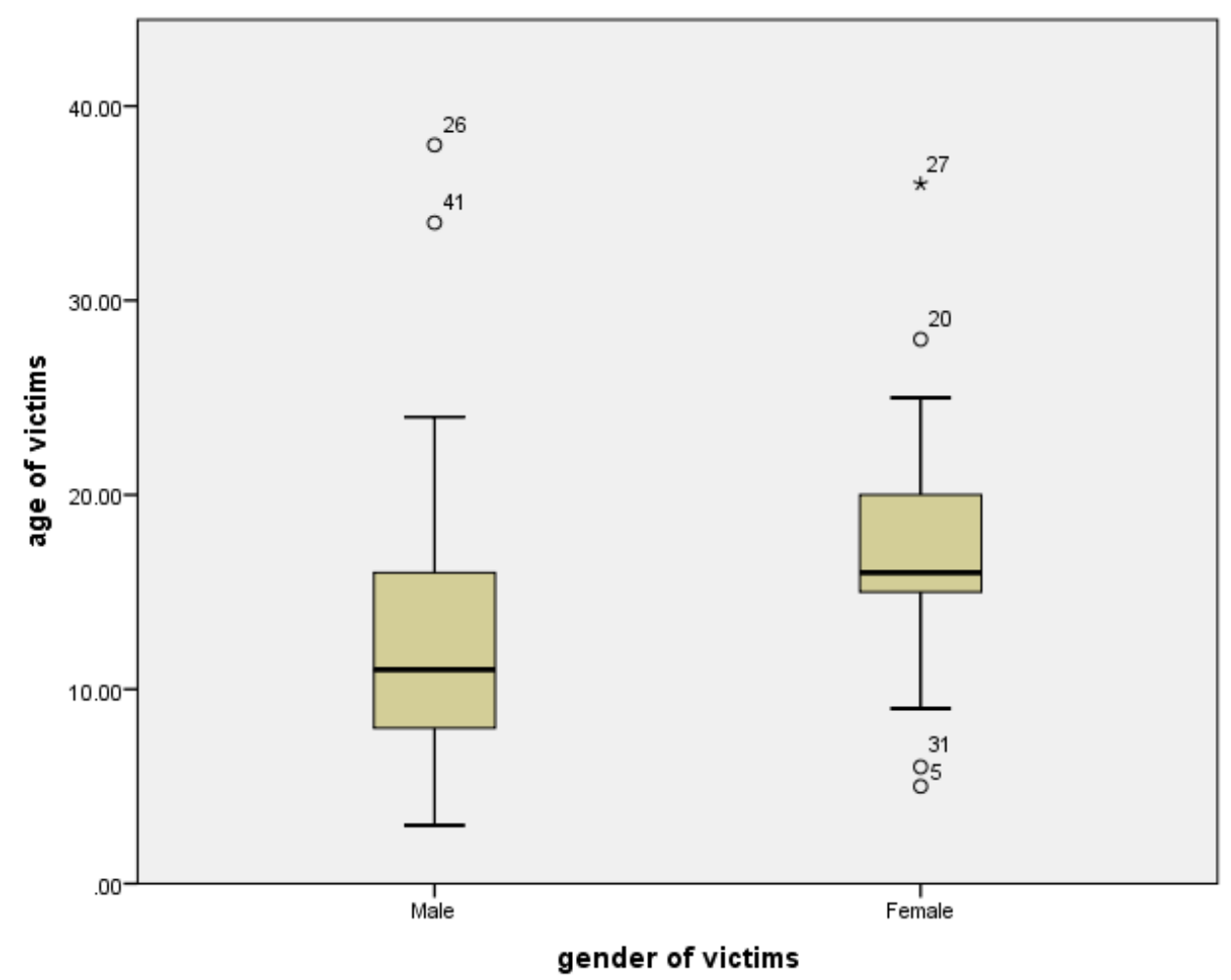

Figure (5): Distribution of victim's age according to gender

Table (6): Age of assailants

\begin{tabular}{|l|l|}
\hline & Age of the assailant \\
\hline Mean & 22 \\
\hline Median & 20 \\
\hline SD & 6.281 \\
\hline Minimum & 15 \\
\hline Maximum & 45 \\
\hline
\end{tabular}

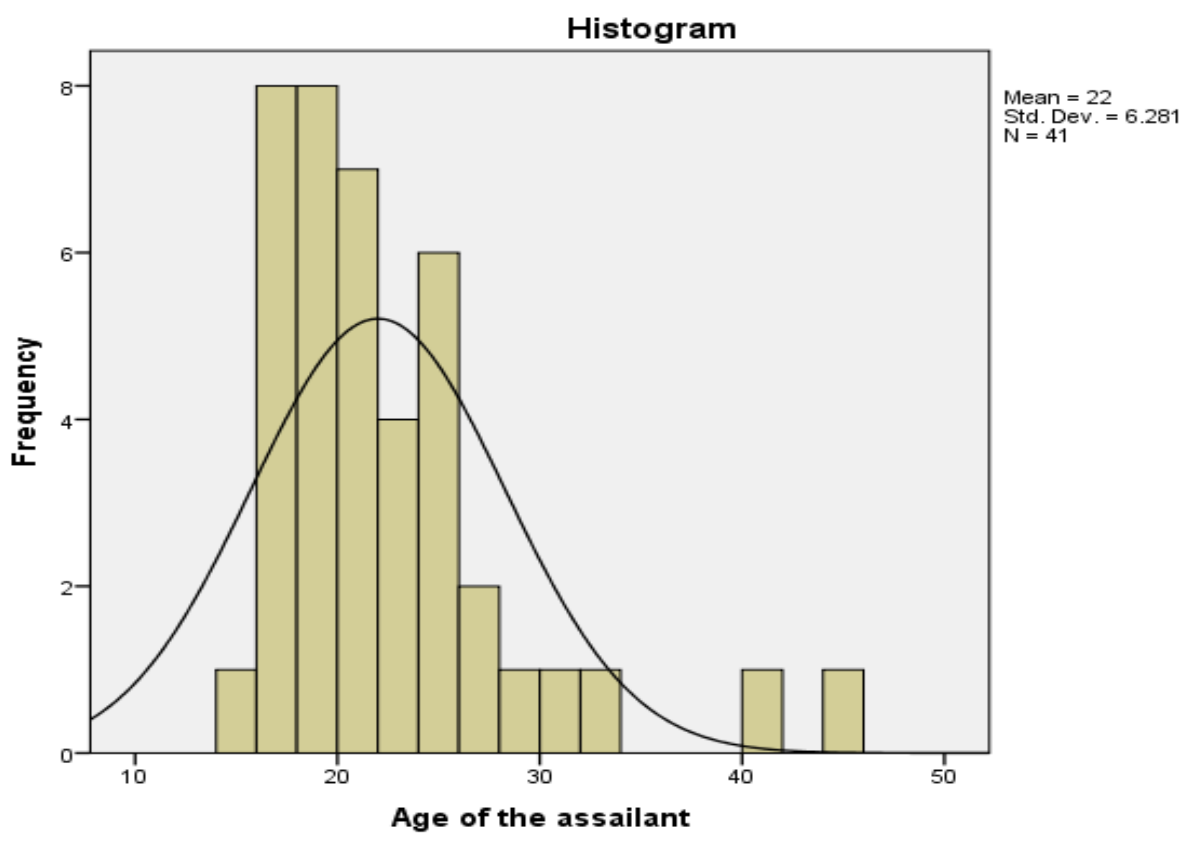

Figure (6): A histogram showing the distribution of assailants' age. 


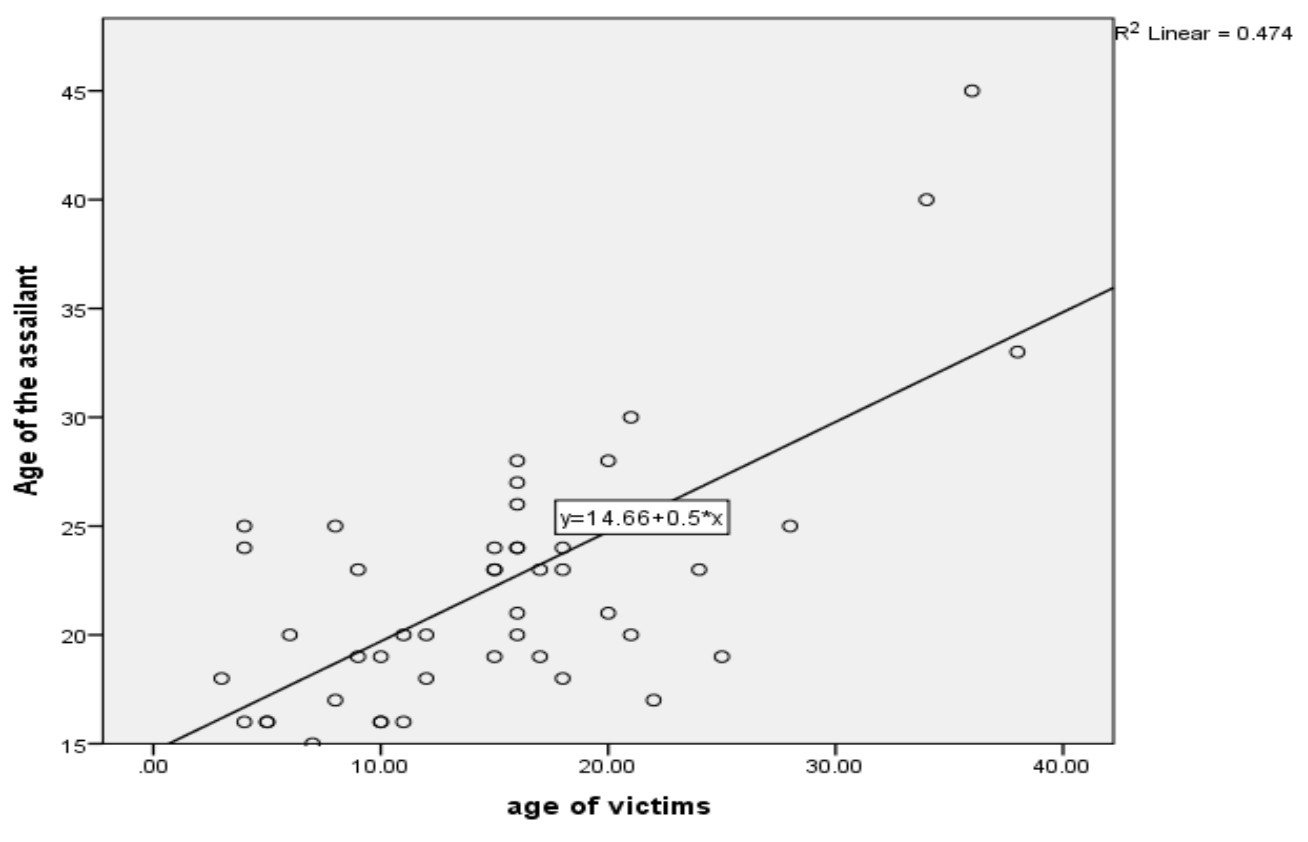

Figure (7): Scatter/dot chart showing the positive correlation between ages of victims and assailants.

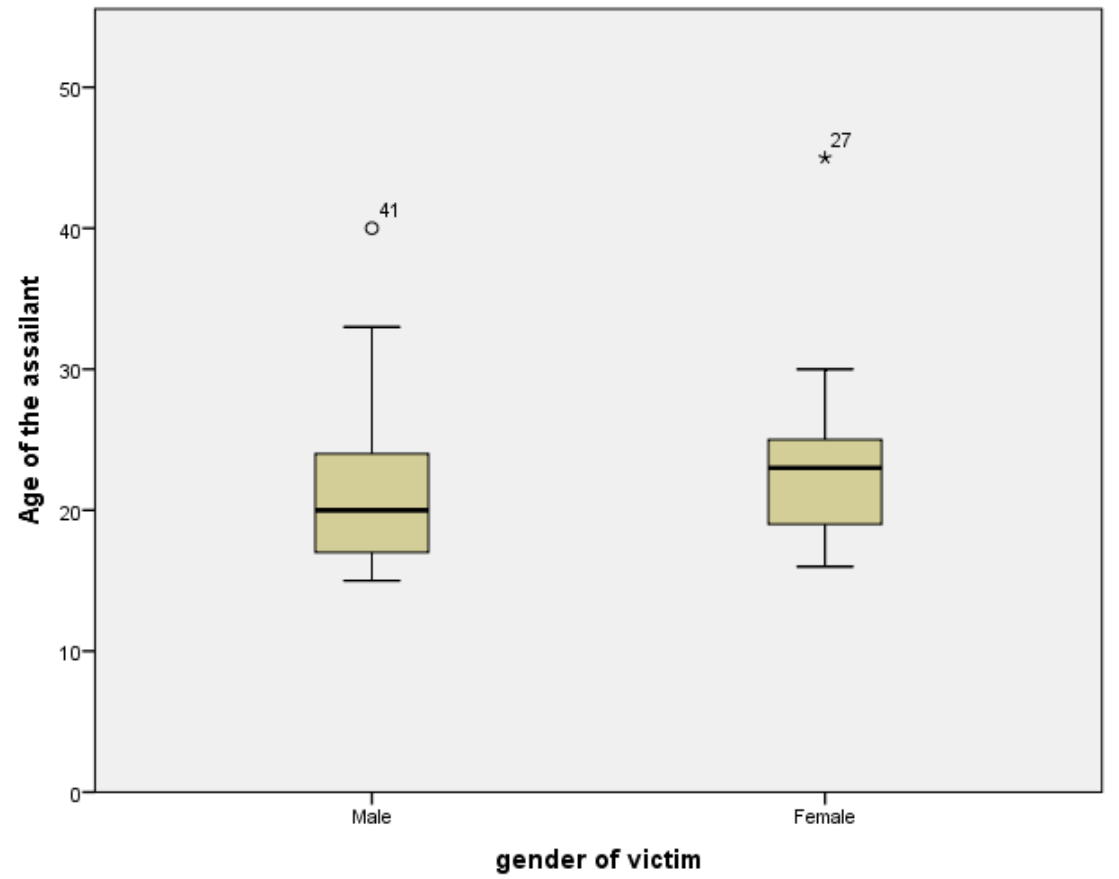

Figure (8): Mean of assailants' age according to victims' gender

Table (7): Distribution of type of assaults among female victims

\begin{tabular}{|l|l|}
\hline Type of Assaults & Frequency (percentage) \\
\hline Vaginal intercourse & $13(61.9 \%)$ \\
\hline Anal intercourse & $2(9.52 \%)$ \\
\hline Anal and vaginal intercourse & $4(19.05 \%)$ \\
\hline Anal fondling & $2(9.52 \%)$ \\
\hline Total & 21 \\
\hline
\end{tabular}


Table (8): Distribution of type of assaults among male victims

\begin{tabular}{|l|l|}
\hline Type of Assaults & Frequency (percentage) \\
\hline Anal intercourse & $22(88 \%)$ \\
\hline Anal fondling & $3(12 \%)$ \\
\hline Total & 25 \\
\hline
\end{tabular}

Table (9): Distribution of anal assaults according to gender of victims

\begin{tabular}{|l|l|}
\hline & Anal intercourse \\
\hline Males & $22(91.66 \%)$ \\
\hline Females & $2(8.33 \%)$ \\
\hline Total & 24 \\
\hline
\end{tabular}

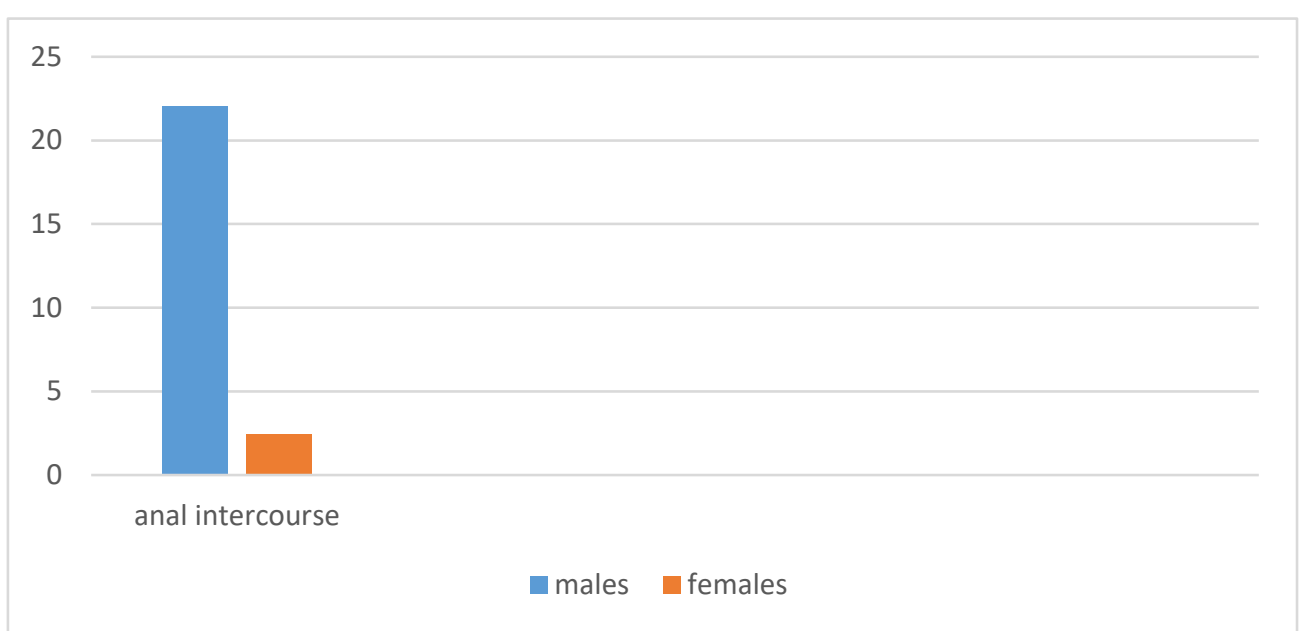

Figure (9): Distribution of anal assault victims according to gender.

Table (10): The first time of presentation of victims of sexual assault.

\begin{tabular}{|l|l|l|}
\hline & Frequency (46) & Percentage \\
\hline After 1 day & 2 & $4.3 \%$ \\
\hline After 2 days & 16 & $34.8 \%$ \\
\hline After 3 days & 10 & $21.7 \%$ \\
\hline After 4 days & 7 & $15.2 \%$ \\
\hline After 6 days & 1 & $2.2 \%$ \\
\hline After 1 week & 2 & $4.3 \%$ \\
\hline After 2 weeks & 2 & $4.3 \%$ \\
\hline After 1 month & 1 & $2.2 \%$ \\
\hline After 2 months & 2 & $4.3 \%$ \\
\hline After 4 months & 1 & $2.2 \%$ \\
\hline After 6 months & 1 & $2.2 \%$ \\
\hline After 1 year & 1 & $2.2 \%$ \\
\hline
\end{tabular}




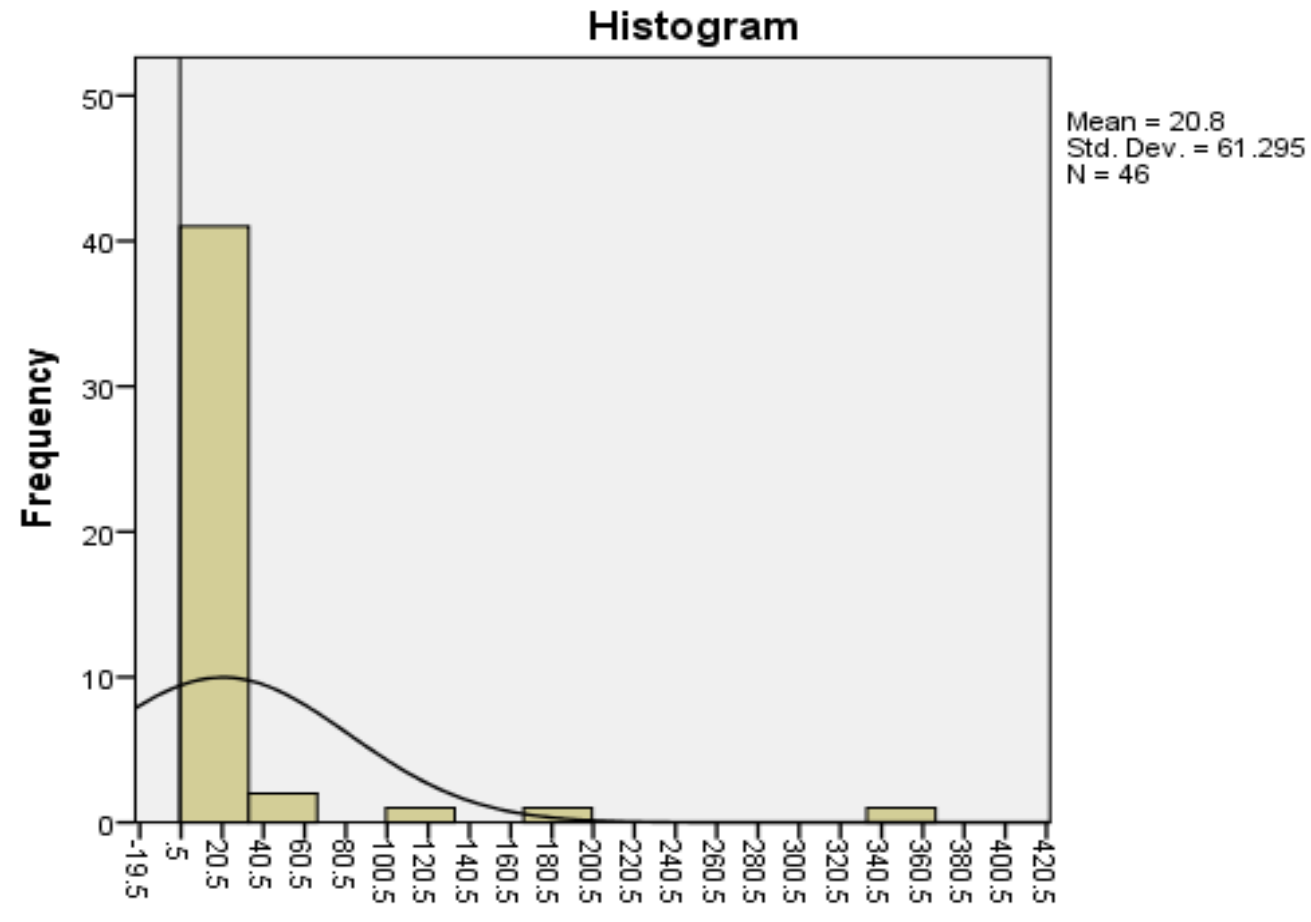

Time

Figure (10): A histogram showing time of presentation of victims of sexual assault.

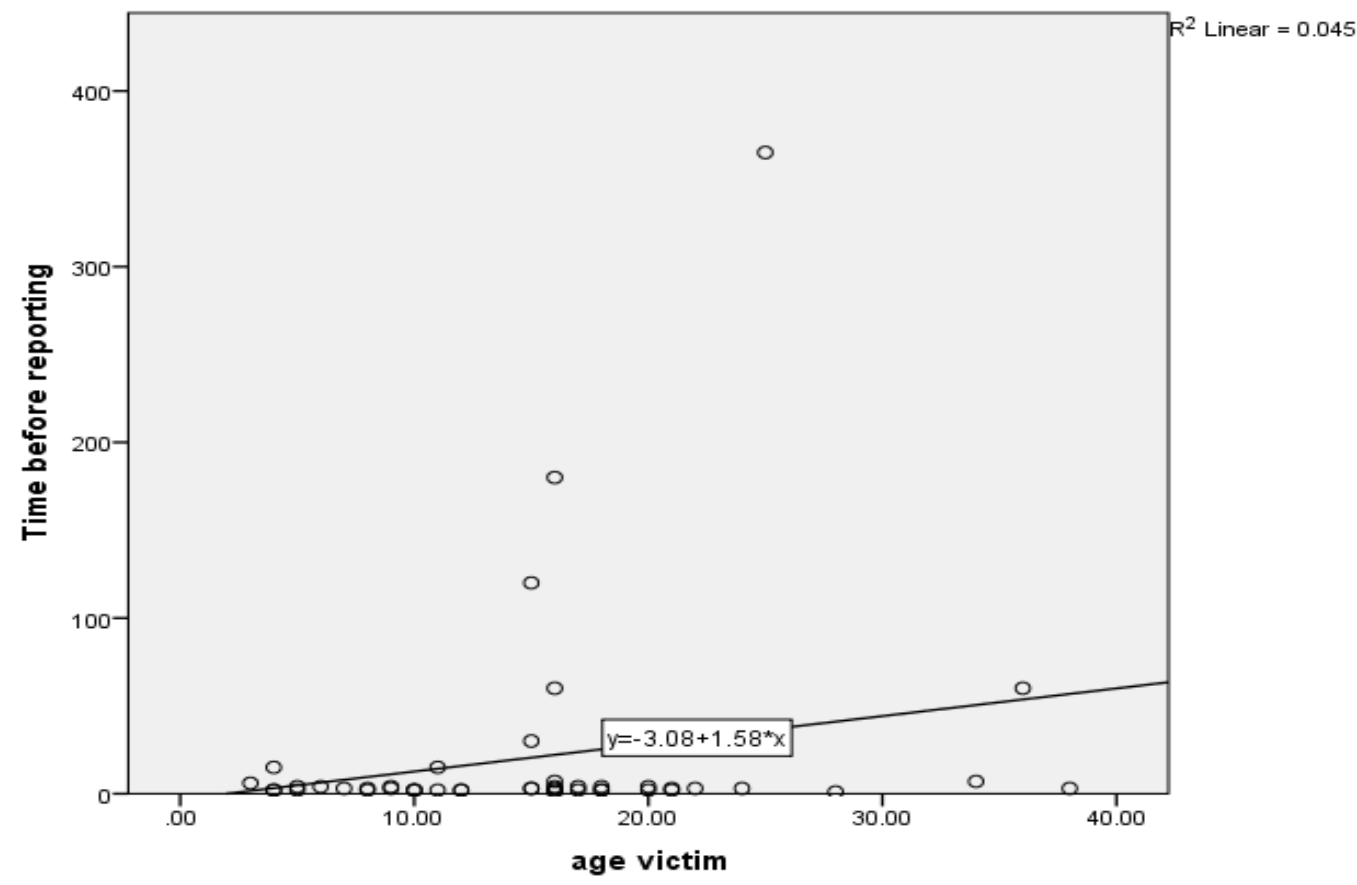

Figure (11): a scatter/dot chart showing a weak positive correlation between age of victim and time passed before reporting the sexual assault. 
Table (11): The history of previous sexual or physical assaults, the presence of general or local signs on examination and detection of seminal fluid.

\begin{tabular}{|l|l|}
\hline $\begin{array}{l}\text { previous sexual or physical } \\
\text { assaults }\end{array}$ & Frequency (percentage) \\
\hline $\begin{array}{l}\text { presence of general signs of } \\
\text { violence on examination }\end{array}$ & $12(26.1 \%)$ \\
4 case contusions \& abrasions on face \\
4 case of contusions abrasions all over the body \\
3 cases of lacerated wound in scalp \\
1 case of lacerated wounds in scalp \& skull \\
fractures
\end{tabular}

Table (12): sex and cause of death in sexual assault victims who died.

\begin{tabular}{|l|l|l|}
\hline & Number of cases & Cause of death \\
\hline Males & 1 & Brain lacerations \\
\hline Females & 3 & $\begin{array}{l}\text { Poisoning by hair } \\
\text { dye }\end{array}$ \\
\hline Total & 4 & \\
\hline
\end{tabular}

\section{DISCUSSION}

Sexual assault is a crime that ranges from sexual coercion and contact abuse (touching, or fondling) to rape (Basson and Baram, 2012). Most literature suggests that most of sexual assault victims are females (Mugawe and Powell, 2006). In the current study, 46 cases of sexual assaults were reported to forensic medicine authority in Aswan governorate from 2010 to 2015 were analyzed. The current results showed that male victims represented $54.3 \%$ of the reported cases, while females represented $45.7 \%$. All the assailants were males. This agrees with a previous study in Qena governorate which also reported that most of the sexual assault victims were males (57.5\%) (Metwaly et al., 2013). While a similar study in Assiut governorate revealed that females represent (60 cases, $69 \%$ ) and males represent (27 cases, $31 \%$ ) of sexual assault cases in years of (2003-2007) (Thabet, 2008). It is postulated that less than one-fourth of female victims report sexual assault to the police (Mugawe and Powell, 2006).

Sexual assaults against males is a significant problem, though; it has been neglected in research (WHO, 2002). Recently males are increasingly identified as victims of sexual assault, and they are blamed more than female victims and suffer from negative judgment due to societal stereotypes that a man should be able to fight back (Davies et al., 2001). Male children approaching adulthood are subjected to 
the same negative judgment as adult males (Davies and Rogers, 2006).

The results of the current study showed that $42(91.3 \%)$ of victims were unmarried, while married victims represented only $8.7 \%$ (4) of cases. This agrees with a retrospective analysis of forensic reports of sexual assaults in Brazil (2005 to 2009), which concluded that $98.8 \%$ of sexual assault victims were single (Rafaella et al., 2015). It is well known that being unmarried is one of 4 lifestyles (alcoholism, being unmarried, previous sexual assaults and living on a campus) that increases the risk of being a victim of sexual assaults (Walsh and Ellis, 2007).

The current results showed that the mean age of sexual assault victims was $15.15 \pm 8.22$ years and $71.74 \%$ of reported cases were under 18 years old. This agrees with a study conducted in two hospitals in Addis Ababa, which assessed 170 cases of sexual assault and revealed that majority of victims were children of less than fifteen years (Lakew, 2001). Some studies in the united states of America stated that more than $50 \%$ of the children who were victims of sexual assaults were between 15-17 years old (Finkelhor et al., 2008). Sexual assault of children is a universal problem with grave lifelong outcomes (WHO, 2014). An estimated $7.9 \%$ of males and $19.7 \%$ of females universally faced sexual abuse before the age of 18 years (Wihbey, 2011). The highest prevalence rate of child sexual assaults is in Africa (34.4\%) (Behere and Mulmule, 2013).

The results of the present study showed that the mean of assailant's age was $22 \pm 6.821$ with minimum age was 15 years and the maximum age was 45 years. No significant difference in age of assailants attacking female or male victims.

In our study; 9 offenders were juveniles (less than 18 years), all victims of juvenile offenders were children (from 3 to 11 years), 8 out of 9 victims were male children representing $88.88 \%$ of victims. Only one juvenile offender assaulted a female child. 37 of offenders were adults (above 18 years). 23 victims of adult offenders were less than 18 years (from 3 to 17 years), representing $62.16 \%$ of their victims. Adult victims were the target of adult offenders in 14 cases representing $37.84 \%$.

Many statistics indicated that many sexual assaults are committed by minors (Dolan et al., 1996). Juvenile sex offenders are also much more likely than adult sex offenders to target young children as their victims. $20 \%$ of all rapes and $20-50 \%$ of child sexual assaults are committed by children (Deisher et al., 1982).

The current results showed that $89.1 \%$ of the cases were either anal or vaginal penetration or both $(52.1 \%$, $28.3 \%$, and $8.7 \%$ respectively). This is in accordance with results of Hassan et al. (2016) which demonstrated that most of cases $(70.6 \%)$ of sexual assaults in Nigeria was penetrative. Our results showed that $84.62 \%$ of anal penetrative assaults victims were males, one of those victims was a prisoner. Sexual assault of men is a well recognized as an old method for humiliating and torturing enemies or as a sexual outlet in institutions where the heterosexual sexual relation is impossible like prisons (Lunde and Ortmann, 1990).

A study in Nigeria demonstrated that majority of sexual assaults on males was anal penetration (75.0\%), concluding the fact that offenders are 
men that have sex with men (Ezechi et al., 2016). Our study showed that only 3 males experienced anal fondling and all other victims experienced forcible anal penetration.

The presence of general body injury is mainly related to circumstances of the assault, while genital and anal injuries are mainly related to victim age, virginity, and time of examination (Sugar et al., 2004). The current result showed that $26.1 \%$ of cases had positive signs of general violence or struggle. General body injuries after a sexual assault can be relatively minor as scratches and bruises. However, some victims may suffer fractures, lacerations, firearm injury, or even death (Tjaden and Thoennes, 2000). General injuries confirm violence and struggle; thus, it is a significant evidence, however, the absence of injuries does not eliminate the possibility of the assault (Reis et al., 2004). The absence of general signs of violence on victim's body may be explained by the long interval between the assault and reporting or by being threatened by a weapon such as knives, and firearms (Kunnuji and Esiet, 2015). While verbal threats are used against children, the use of weapons is more likely to be used against adult victims, because victims have greater physical size and strength to resist (Rafaella et al., 2015).

$60.9 \%$ of cases of the current study showed genito-anal injury. These injuries ranged from contusions and abrasions around the anus to recent cut of hymen or anus. Some cases showed old hymen tears and others showed signs of habitual sodomy (anal penetration).

The pattern of local injuries has a very significant medico-legal importance as injuries are linked to the outcome of legal proceedings (Sommers, 2007). The likelihood of local genital injury due to sexual assault is unclear and often is an issue in court proceedings. Conviction rates are higher when the victim has genital injuries (Palmer et al., 2004). A study in Ethiopia showed that genital injuries were present in $75.4 \%$ of rape victims and genital injuries were associated with general body injuries in $19 \%$ of cases. The occurrence of genital or anal injury during the assault increase the risk of acquisition of HIV infection (Amenu and Hiko, 2014). Death due to genital injuries was encountered in extreme cases of sexual assaults. Ashcraft (2000) documented two deaths due to rectal trauma resulting from sexual assault, causing laceration of the peritoneum and peritonitis.

The results of this study showed that one male victim was deceased and demonstrated fatal skull fractures, and three female victims had died by fatal doses of hair dye. The father of the victim, not sexual offenders, poisoned two of the murdered females. Deaths following sexual violence may be suicidal or homicidal (Miller, 1999). Homicidal death occurs either during the sexual assault or after the assault as a murder of "honor" (Mercy et al., 1993). Murders committed by the perpetrator are usually committed to conceal his identity (Badejoko et al., 2014).

The current results showed that the mean interval between the assault and reporting was $20.8 \pm 61.295$ days with 3 days interval being the most frequent $(34.8 \%)$ with a range between 1 day and 1 year. In another study in Ethiopia, the average time for reporting was 34.6 days, the range is 2 hours to 2 years (Feleke and Ahmed, 2009). The wide variation in the interval between 
reporting and assault may be due to threats, children believe threatening of the assailant and usually, they disclose the assault after the offending is discovered by one of the parents (Lessing, 2005).

The current results demonstrated that seminal fluid was detected in only $13 \%$ cases. Amenu and Hiko (2014) demonstrated that vaginal swabs from $25.2 \%$ of sexual assault victims that managed in a specialized hospital in Ethiopia were found to be positive for sperms in $44 \%$. It is well known that as the interval between the assault and examination of the victims lengthens, the opportunity to detect trace evidences decreases the quality of forensic evidences (WHO, 2003). The probability of collecting evidence decrease over time. Ideally, samples should be collected within 24 hours of the assault; after 72 hours, the yield is greatly reduced (Ingemann et al., 2008).

\section{CONCLUSION}

Male victims represent more than half of reported sexual assaults and mostly were adolescents and unmarried.

\section{RECOMMENDATION}

It is necessary to emphasize that males also could be victims of sexual assault and male children are at significant risk of sexual abuse, to improve preventive measures.

The presence of a specialized center to deal with sexual assault cases with the presence of trained stuff for rapid examination collection of samples with secrecy and confidentiality.

\section{REFERENCES}

Akinlusi FM, Rabiu KA, Olawepo TA, Adewunmi AA, Ottun TA, (2014): Sexual Assault in Lagos, Nigeria: A Five Year Retrospective Review. Akinola OIBMC Womens Health. 23 (14):115.

Amenu D; and Hiko D. (2014): Sexual Assault: Pattern And Related Complications Among Cases Managed In Jimma University Specialized Hospital. Ethiop J Health Sci.;24(1):3-14.

Ashcraft KW. (2000): Acquired Anorectal Disorders. In: Ashcraft KW, Murphy JP, Sharp RJ, Sigalet DL, Snyder CL, eds. Pediatric Surgery. Philadelphia: WB Saunders;. pp. 511-7.

Badejoko OO, Anyabolu HC, Badejoko BO, Ijarotimi AO, Kuti O, Adejuyigbe EA (2014): Sexual Assault In Ile-Ife, Nigeria. Niger Med J. 2014 May; 55(3):254-9.

Basson R; and Baram DA. (2012): Sexuality, Sexual Dysfunction, And Sexual Assault. In: Berek JS, editor. Berek \& Novak's gynecology. 15th ed. Philadelphia (PA): Wolters Kluwer Health/Lippincott Williams \& Wilkins; pp. 270-304

Behere PB; and Mulmule AN. (2013): Sexual Abuse In 8 Year Old Child: Where Do We Stand Legally? Indian J Psychol Med. 2013 35:203-5. Available from:www.ijpm.info/article.asp?iss $\mathrm{n}=$ 0253-7176; year 35;Behere .

CAPMAS (2016): Statistical Yearbook - Population. Central Agency for Public Mobilization and Statistics.

Davies $M$ and Rogers $P$ (2006): Perceptions Of Male Victims in Depicted Sexual Assaults: A review of the literature. Aggression and Violent Behavior 11: 367-377 
Davies, M., Pollard, P., \& Archer, J. (2001): The Influence Of Victim Gender And Sexual Orientation On Judgments Of The Victim In A Depicted Stranger Rape. Violence and Victims, 16, 607-619

Deisher RW, Wenet GA, Paperny DM, Clark TF, Fehrenbach PA (1982): Adolescent Sexual Offence Behaviour: The Role of the Physician. J. Adolescent Hlth Care 2:279-86.

DeVore HK; and Sachs CJ (2011): Sexual Assault. Emerg Med Clin North Am. 29(3):605-620.

Dolan M, Holloway J, Bailey S, Kroll L (1996): The Psychosocial Characteristics of Juvenile Sexual Offenders Referred to an Adolescent Forensic Service in the UK . Med Sci Law. 36(4):343-52.

Du Mont J; and White D (2007): , The Uses and Impacts of Medicolegal Evidence in Sexual Assault Cases: A Global Review , 2007GenevaWorld Health Organization

http://www.svri.org/medico.pdf

Ezechi OC, Adesolamusa Z, David AN, Wapmuk AE, Gbajabiamila TA, Eugeniaidigbe I, Ezeobi PM, Ohihoin AG, and Ujah IAO (2016): Trends And Patterns Of Sexual Assaults In Lagos SouthWestern Nigeria. Pan Afr Med J; 24: 261.

Feleke W; and Ahmed A. (2009): Emergency Contraception Provision for Sexually Assaulted Women at Health Facilities In Addis Ababa, Ethiopia. Ethiopian Journal of Reproductive Health. 3(1):52-58.

Finkelhor David, Heather Hammer, Sedlak AJ. (2008): Sexually Assaulted Children: National Estimates and Characteristics, in
OJJDP: Juvenile Justice Bulletin. US Department of Justice. 2008. https://www.ncjrs.gov/pdffiles1/ojj dp/214383.pdf. Accessed 21 August, 2017.

Hassan M, Awosan KJ, Panti AA, Nasir S, Tunau K, Umar AG, Shehu CF, Ukwu AE, and Sulaiman1 B (2016): Prevalence and Pattern Of Sexual Assault In Usmanu Danfodiyo University Teaching Hospital, Sokoto, Nigeria Pan Afr Med J. 24: 332.

Ingemann O. H. , Brink O. , Sabroe S., Sørensen V. and Charles A. V. (2008): Legal aspects of sexual violence-Does forensic evidence make a difference?, Forensic Sci. Int. 180(2-3): 98-104.

Kunnuji MO; and Esiet A (2015): Prevalence And Correlates of Sexual Abuse Among Female out of School Adolescents In Iwuya Community, Lagos state, Nigeria. Afr J Reprod Health. 19(1): 82-90.

Lakew $Z$ (2001): Alleged Cases of Sexual Assault Reported To Two Addis Ababa Hospitals. East Afr Med J. 78(2):80-3.

Lessing JE (2005): Primary Care Provider Interventions for the Delayed Disclosure of Adolescent Sexual Assault. J Pediatr Health Care. 19(1):17-24

Lunde I; and Ortmann J. (1990): Prevalence and Sequelae of Sexual Torture. Lancet 1990;336:289-91.

Masho SW; and Anderson L. (2009): Sexual Assault In Men: A Population-Based Study Of Virginia. Violence Vict. 24(1):98110.

Mercy JA et al. (1993): Intentional Injuries. In: Mashaly AY, Graitcer $\mathrm{PH}$, Youssef ZM, eds. Injury In Egypt: An Analysis Of Injuries As 
A Health Problem. Cairo, Rose El Youssef New Presses, 1993:65-84.

Metwaly M, Ismail MA, Sherif MM, Mahmoud SF, Mohammed IN, Assasa MF (2013): Study about Sexual Offences in Qena Governorate. Z.U.M.J.Vol.19; N.2; 276:289.

Miller M. A (1999): Model to Explain The Relationship Between Sexual Abuse And HIV Risk Among Women. AIDS Care, 11:3-20. 26.

Mugawe D, Powell A. (2006): Born to High Risk: Violence against Girls in Africa. The African Child Policy Forum.

Palmer CM, McNulty AM, D'Este C, Donovan B. (2004): Genital injuries in women reporting sexual assault. Sex Health. 1 (1):55-9.

Rafaella Q. Souto, Francisco K. C. D. Araújo, Alidianne F. C. Xavier, Alessandro L. Cavalcanti (2015): Rape against Brazilian Women: Characteristics of Victims and Sex Offenders. Iranian Journal of Public Health . 44(12):1613-1619.

Reis JN, Martin CC, Ferriani Md Cad Saude Publica. (2004): Female Victims of Sexual Abuse: Coercive Methods and Non-Genital Injuries. Mar-Apr; 20(2):465-73.

Seña AC, Hsu KK, Kellogg N, Girardet R, Christian CW, Linden J, Griffith W, Marchant A, Jenny C, Hammerschlag MR (2015): Sexual Assault and Sexually Transmitted Infections in Adults, Adolescents, and Children. Clin Infect Dis. 15(61):856-864.

Sommers MS (2007): Defining patterns of genital injury from sexual assault: a review. Trauma Violence Abuse. 8(3):270-80.

Sugar NF, Fine DN, Eckert LO. (2004): Physical injury after sexual assault: findings of a large case series. Am J Obstet Gynecol. 190(1):71-6.

Thabet H.Z (2008): Assessment of Sexual Assault Cases in Assuit Governorate. Egypt J. Forensic Sci. Appl. Toxicol. 8(1)

Tjaden P; and Thoennes N. (2000): Full Report Of The Prevalence, Incidence, And Consequences Of Violence Against Women: Findings From The National Violence Against Women Survey. NCJ 183781. Washington, DC: U.S. Department of Justice, Office of Justice Programs. Available at: http://www.ncjrs.gov/pdffiles $1 / \mathrm{n}$ ij/183781.pdf. Accessed 15 August 2017.

Walsh A. and Ellis L. (2007): Criminology: An Interdisciplinary Approach. "victimology: exploring the experience of victimization" $1^{\text {st }}$ ed. Ch. 16 pp 427-44

WHO (2002): World Report on Violence and Health, ch 6, Sexual Violence pp.149-181

WHO (2003): World Health organization. Guidelines For Medico-Legal Care For Victims Of Sexual Violence: Child sexual abuse. $\quad$ pp: 75-93. http://whqlibdoc.who.int/publicatio ns/2004/924154628x.pdf. Accessed 10 August , 2017

WHO (2014): World Health organization. Child maltreatment. Geneva. Available from:http://www.who.int/topics/chi ld_abuse/en/. Accesses 1 september 2017

Wihbey J. (2011): Global prevalence of child sexual abuse. Journalist Resource [Available from: Journalists resource.org/studies/./globalprevalence-child-sexual-abuse 
الملخص العربي

نمط حالات الاعتداء الجنسي المبلغ عنها في محافظة أسوان، دراسة مرجعية .(2015- 2010)

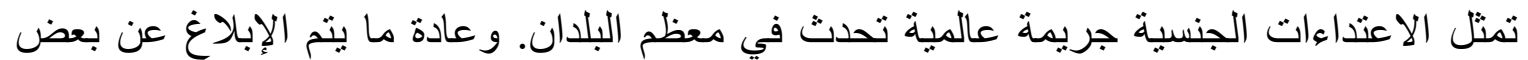

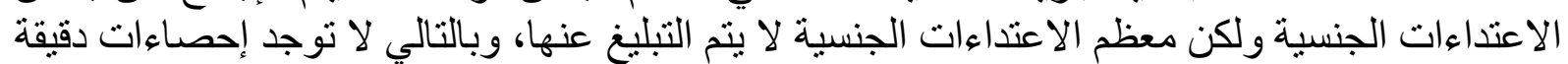

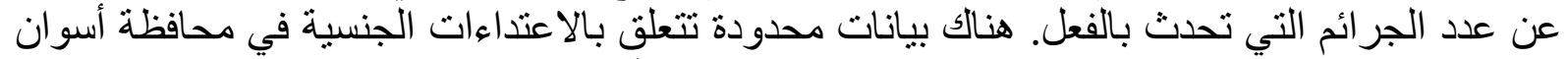

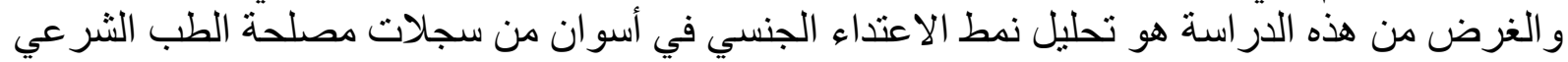

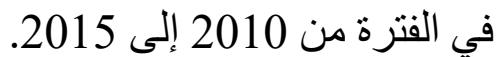
مثل الذكور أكثر من نصف ضحايا الاعتداءات الجنسية المبلغ عنها (54.3\%) وكان معظمهم من المر اهقين وغير المتزوجين. وكان متوسط سن الضحايا 15+15 بينما بلغ منوسط عمر المعتدين 22

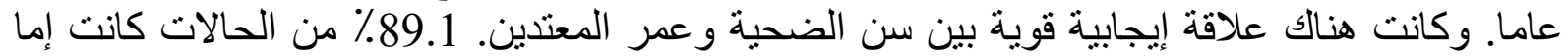

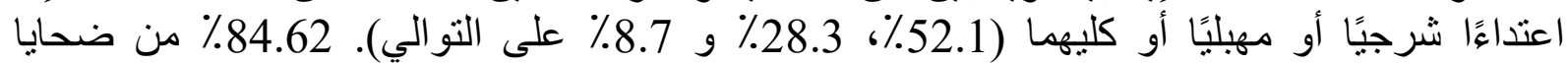

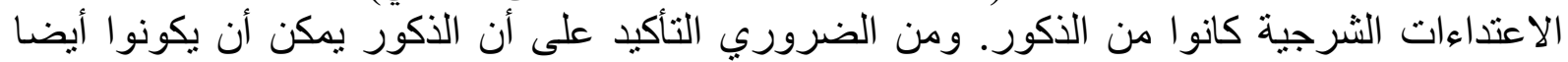

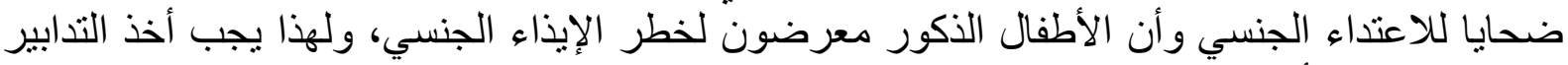
الوقائية لحماية الأطفال. 